\title{
Floodplain management in temperate regions: is multifunctionality enhancing biodiversity?
}

Stefan Schindler ${ }^{1,2^{*}}$, Michaela Kropik ${ }^{1}$, Katrin Euller ${ }^{1}$, Stuart W Bunting ${ }^{3}$, Christiane Schulz-Zunkel ${ }^{4}$, Anna Hermann ${ }^{1}$, Christa Hainz-Renetzeder ${ }^{1}$, Robert Kanka ${ }^{5}$, Volker Mauerhofer ${ }^{6}$, Viktor Gasso ${ }^{7}$, Andreas Krug ${ }^{8}$, Sophie G Lauwaars ${ }^{9}$, Klaus Peter Zulka ${ }^{10}$, Klaus Henle ${ }^{4}$, Maurice Hoffmann ${ }^{11}$, Marianna Biró ${ }^{12}$, Franz Essl ${ }^{10}$, Sophie Jaquier ${ }^{13}$, Lukács Balázs $^{12}$, Gábor Borics ${ }^{12}$, Stephanie Hudin ${ }^{14}$, Christian Damm ${ }^{15}$, Martin Pusch $^{16}$, Theo van der Sluis ${ }^{17}$, Zita Sebesvari ${ }^{18}$ and Thomas Wrbka'

\begin{abstract}
Background: Floodplains are among the most diverse, dynamic, productive and populated but also the most threatened ecosystems on Earth. Threats are mainly related to human activities that alter the landscape and disrupt fluvial processes to obtain benefits related to multiple ecosystem services (ESS). Floodplain management therefore requires close coordination among interest groups with competing claims and poses multi-dimensional challenges to policy-makers and project managers. The European Commission proposed in its recent Biodiversity Strategy to maintain and enhance European ecosystems and their services by establishing green infrastructure (Gl). $\mathrm{Gl}$ is assumed to provide multiple ecosystem functions and services including the conservation of biodiversity in the same spatial area. However, evidence for biodiversity benefits of multifunctional floodplain management is scattered and has not been synthesised.

Methods/design: This protocol specifies the methods for conducting a systematic review to answer the following policy-relevant questions: a) what is the impact of floodplain management measures on biodiversity; b) how does the impact vary according to the level of multifunctionality of the measures; $c$ ) is there a difference in the biodiversity impact of floodplain management across taxa; $d$ ) what is the effect of the time since implementation on the impact of the most important measures; and e) are there any other factors that significantly modify the biodiversity impact of floodplain management measures? Within this systematic review we will assess multifunctionality in terms of ESS that are affected by an implemented intervention. Biodiversity indicators included in this systematic review will be related to the diversity, richness and abundance of species, other taxa or functional groups. We will consider if organisms are typical for and native to natural floodplain ecosystems. Specific inclusion criteria have been developed and the wide range of quality of primary literature will be evaluated with a tailor-made system for assessing susceptibility to bias and the reliability of the studies. The review is intended to bridge the science-policy interface and will provide a useful synthesis of knowledge for decision-makers at all governance levels.
\end{abstract}

Keywords: Biodiversity, Multifunctionality, Floodplain management, Green infrastructure, European Commission Biodiversity Strategy 2020, Biodiversity knowledge, Ecosystem services, Flood prevention, River restoration, Systematic review, Science-policy interface, Science-practice interface

\footnotetext{
*Correspondence: stefan.schindler@univie.ac.at; stefan_schindler75@yahoo.es

'Department of Conservation Biology, Vegetation \& Landscape Ecology,

University of Vienna, Rennweg 14, Vienna 1030, Austria

${ }^{2} \mathrm{CIBIO}$, Centro de Investigação em Biodiversidade e Recursos Genéticos,

Universidade do Porto, Campus Agrário de Vairão, 4485-601 Vairão, Portugal

Full list of author information is available at the end of the article
}

\section{Biomed Central}

(C) 2013 Schindler et al.; licensee BioMed Central Ltd. This is an Open Access article distributed under the terms of the Creative Commons Attribution License (http://creativecommons.org/licenses/by/2.0), which permits unrestricted use, distribution, and reproduction in any medium, provided the original work is properly cited. 


\section{Background}

The European Commission proposed in its recent Biodiversity Strategy to maintain and enhance European ecosystems and their services by 2020 by establishing green infrastructure (GI) and restoring at least $15 \%$ of degraded ecosystems [1]. The package of actions designed to respond to this challenge included the need to ensure no net loss of biodiversity and ecosystem services by EUfunded projects, priority setting regarding restoration, and promoting the use of GI [1]. GI is defined as the network of natural and semi-natural areas, features and green spaces in rural and urban, terrestrial, freshwater, coastal and marine areas [2]. This includes for instance areas of high nature value such as protected areas, floodplains, wetlands and natural forests, natural landscape features that can act as corridors for wildlife, artificial features such as eco-ducts or eco-bridges, and multifunctional zones where land uses are favoured that help maintain or restore healthy biodiverse ecosystems [3,4]. The European Commission emphasizes the ability of GI to perform multiple functions in the same spatial area, thus sustaining a range of benefits by delivering multiple ecosystem services (ESS) such as air and water purification and climate regulation $[5,6]$. ESS represent the benefits human populations derive, directly or indirectly, from ecosystem functions [7], and both functions and benefits might be affected through interventions, such as reconnection of natural areas and improvement of overall ecological quality of the countryside. A combination of the delivery of multiple ESS including the conservation of biodiversity could lead to win-win situations and thus present an efficient way of achieving long-term nature conservation [8]. Knowledge generation to promote understanding of such situations is a current research priority in conservation biology, applied ecology, and environmental sciences $[9,10]$. Within this systematic review we will assess multifunctionality in terms of ESS that are affected by an implemented intervention.

Floodplains develop adjacent to river channels and can be described as low-relief Earth surfaces composed of fluvial deposits $[11,12]$ that are frequently flooded (active floodplains) or formerly flooded (morphological floodplains) and are an integral part of catchments [13]. While hosting important natural assets and high levels of biodiversity [14-16], they have been used since ancient times by human populations, who attempted to maximize the benefits they gained by interventions such as irrigation channels and dikes [17]. In many parts of the world, human activities have altered the landscape and disrupted fluvial processes to the extent that floodplains are among the world's most threatened ecosystems [18-20]. Floodplains are good examples for multifunctional landscapes and GI and their management requires close coordination among agriculture, water use, hydrological engineering, mineral extraction, energy production, nature conser- vation and spatial planning [21] and poses multidimensional challenges to policy-makers and project managers [22]. Flood protection is particularly important in light of an increasing frequency and amplitude of flood events throughout Europe, resulting in casualties and damage [23,24]. Restoration of a river and its adjacent floodplain might generate many benefits for nature and society, including alternative economic activities, improved flood prevention, richer biodiversity and aesthetically appealing landscapes and particular recreational opportunities. However, information on implementation and outcomes of such projects is often inaccessible [25].

Evidence for biodiversity effects of the GI approach and particularly of multifunctional floodplain management is scattered and has not been synthesised [21]. This issue is of particular relevance for large lowland floodplains, where due to high human population densities a variety of ecosystem services are in demand while at the same time floodplain biodiversity is driven by dynamic biophysical processes and feedback mechanisms over broad spatial and temporal scales [13,17]. As climate is an important factor for ecological processes, floodplains situated in climates comparable to those occurring in Europe are of particular relevance for this review that aims to support European decision-making. Floodplain interventions are very diverse [26] and in this scientific review we will hierarchically categorize the encountered interventions with respect to their main aims and effects. The interventions also differ strongly regarding the frequency of their implementation and the degree to which their impact on biodiversity has been assessed or results published in accessible formats [25]. This must be considered when interpreting the results of this review. The level of multifunctionality of interventions can be assessed in terms of their effects on ESS. For instance, several restoration measures aiming at a dynamic habitat mosaic are supposed to additionally increase the provision of ESS, such as water purification and lifecycle maintenance, habitat and gene pool protection [13]. Suitable indicators of biodiversity include measures such as the diversity or abundance of species, taxonomic or functional groups [27-30]. The effects of the floodplain management measures on biodiversity will be prone to several factors, the most obvious being the considered taxa and the time since intervention. Floodplain management measures can have very different effects on different taxa, for instance, a water enhancement scheme for the Danube floodplain within the city limits of Vienna showed positive effects on dragonflies and molluscs, while no significant impact was observed for fish [31]. Time since intervention is a crucial parameter, and depending on several factors, such as availability of propagules for population establishment, an intervention might show its effects only after a considerable time span [32]. 


\section{Objective of the review}

In this systematic review we aim to synthesise evidence in response to a two-part primary question dealing with the effects of multifunctional floodplain management on biodiversity. We will further assess three secondary questions dealing with the main causes of heterogeneity in patterns detected.

\section{Primary question}

What is the impact of floodplain management measures on biodiversity and how does the impact vary according to the level of multifunctionality of the measures?

The question contains the following components:

Population: floodplains and rivers, including all ecosystems that are located in the morphological floodplain and linked to the hydrological regime of the river.

Intervention: floodplain management measures, commonly related to production and transport (e.g. water or mineral extraction, navigational infrastructure), water regulation and flood protection, conservation and restoration as well as recreation activities (see Methods section for further examples).

Comparator: the previous state of the floodplain before the implementation of the intervention, the original natural state of the floodplain, or the state of the floodplain after another kind of intervention.

Outcome: change in biodiversity indicators (diversity and abundance indicators of species or other groups of organisms).

\section{Secondary questions}

a) How does the biodiversity impact of floodplain management differ across taxa?

b) What is the effect of the time since implementation on the impact of floodplain management measures?

c) Which other factors significantly modify the biodiversity impact of floodplain management measures?

\section{Methods}

\section{Searches}

\section{Database search terms and languages}

Three categories of search terms will be applied, corresponding to the categories of the questions, i.e. population, intervention and outcome (Tables 1, 2 and 3). The comparator will not be included for the search itself but as an inclusion criterion. We aim to perform the search in the

Table 1 Search terms for the population "floodplains"

\begin{tabular}{lll}
\hline & \multicolumn{2}{c}{ Population } \\
\hline flood $^{*}$ & oxbow & ripari* \\
inundat* & river & tributar* $^{*}$ \\
\hline
\end{tabular}

Table 2 Search terms for the intervention "floodplain management"

\begin{tabular}{|c|c|c|}
\hline \multicolumn{3}{|c|}{ Interventions } \\
\hline General terms & habita* renaturali* & water* rehabil* \\
\hline alluvi* *${ }^{*}$ connect* & habita* restor* & water* renaturali* \\
\hline alluvi* manag* & in-stream ${ }^{*}{ }^{*}$ connect ${ }^{*}$ & water* $^{*}$ restor* \\
\hline alluvi* measur* & in-stream* manag* & Specific terms \\
\hline alluvi* rehabil* & in-stream* measur* & bank fixation \\
\hline alluvi* renaturali* & in-stream* rehabil* & bank stabilization \\
\hline alluvi* restor* & in-stream* renaturali* & boulder additions \\
\hline aquati* ${ }^{*}$ connect ${ }^{*}$ & in-stream* restor* & channel reconfiguration \\
\hline aquati* manag* & multifunct ${ }^{*}$ connect $^{*}$ & connectivity at hydraulic facilities \\
\hline aquati* $^{*}$ measur* & multifunct* manag* & creat* $^{*}$ a water course \\
\hline aquati* $^{*}$ rehabil* & multifunct* measur* & creat $^{*}$ of multi* chann* \\
\hline aquati* renaturali* & multifunct* rehabil* & dam removal \\
\hline aquati* $^{*}$ restor* & multifunct* renaturali* & elong* of river length \\
\hline channel* ${ }^{*}$ connect* & multifunct* restor* & fish passage \\
\hline channel* manag* & ripari* *${ }^{*}$ connect* & flow modification \\
\hline channel* measur* & ripari* manag* & flow regulation \\
\hline channel* rehabil* & ripari* measur* & install* of flow deflect* \\
\hline channel* renaturali* & ripari* rehabil* & land acquisition \\
\hline channel* $^{*}$ restor* & ripari* renaturali* & lower* of entrench* depth \\
\hline floodplain *${ }^{*}$ connect ${ }^{*}$ & ripari* restor* & modifying flows \\
\hline floodplain manag* & river ${ }^{*}$ connect $^{*}$ & morphological alteration \\
\hline floodplain measur* & river manag* & reconnection \\
\hline floodplain rehabil* & river measur* & re-connection \\
\hline floodplain renaturali* & river rehabil* & reconfiguring river \\
\hline floodplain restor* & river renaturali* & river continuity \\
\hline habita* ${ }^{*}$ connect $^{*}$ & river restor* & river widening \\
\hline habita* manag* & water* ${ }^{*}$ connect $^{*}$ & stormwater management \\
\hline habita* measur* $^{*}$ & water* manag* & water abstraction \\
\hline habita* rehabil* & water* measur* & wood placement \\
\hline
\end{tabular}

two main databases for scientific literature, i.e. Scopus and Thomson Reuters Web of Knowledge (formerly ISI Web of Knowledge). The main search terms for each category will be complemented by alternative terms deemed by the review team to have similar significance given the terms have been applied in several key papers [26,33-35]. Among the three categories, the terms will be linked with the Boolean operator 'AND'. Within the three categories, the terms will be linked with the Boolean operator 'OR'. In the "outcome-group", the main search term "biodiversity" will be complemented by a combination of (i) any of the four terms "diversity", "richness", "abundance", and "density" AND (ii) any of many alternative terms for "species", such as "genus", "taxon", "plant", "tree", "bird", "insect", "macrozoobenthos", etc. (Table 3). To be considered, studies will have to contain one term for each of the three categories in either title, keywords and abstract or topic for 
Table 3 Search terms for the outcome "biodiversity" following the formula "biodivers* OR (group1 AND group2)"

\begin{tabular}{|c|c|c|c|}
\hline \multicolumn{4}{|c|}{ Outcome } \\
\hline \multicolumn{4}{|l|}{ group1-terms } \\
\hline abundance & density & divers* & richness \\
\hline \multicolumn{4}{|l|}{ group2-terms } \\
\hline species & plants & animals & animals (cont.) \\
\hline *bentho* & *alga* & amphib* & mammal* \\
\hline family & *annual* & animal* & meiofauna* \\
\hline fung* & bryophyte* & $a n t^{*}$ & mollusc* \\
\hline genus & $\left.{ }^{*} \cot y\right|^{*}$ & arthropod* & moth* \\
\hline microorganism* & epiphyte* & avian* & mussel \\
\hline organism* & fern* & bee $^{*}$ & nematode* \\
\hline parasite* & forb* & beetle* & newt \\
\hline pelagic* & $\operatorname{grass}^{*}$ & bird* $^{*}$ & omnivore* \\
\hline${ }^{*}$ plancton* & liana* & butterfly* & $o w l^{*}$ \\
\hline *plankton* & orchid* & carabid* $^{*}$ & passerine ${ }^{*}$ \\
\hline saprophyte* & perennials* & carnivore ${ }^{*}$ & pollinator* \\
\hline species & plant* & caterpillar* & raptor* \\
\hline taxa & tree* & cricket $^{*}$ & reptile* \\
\hline \multirow[t]{10}{*}{ taxon } & & detritivore* & snail ${ }^{*}$ \\
\hline & & ${ }^{*}$ fauna* & snake* \\
\hline & & fish* & toad \\
\hline & & frog $^{*}$ & tortoise \\
\hline & & grasshopper* & turtle \\
\hline & & grazer* & ${ }^{*}$ vertebrate ${ }^{*}$ \\
\hline & & herbivore* & wader* \\
\hline & & insect* & wasp* \\
\hline & & larva* & woodpecker* \\
\hline & & lizard* & \\
\hline
\end{tabular}

the Scopus or Thomson Reuters Web of Knowledge databases, respectively.

Thus the total search string will have the following structure:

(Population-Term-1 OR Population-Term-2 OR ... OR Population-Term-n) AND

(Intervention-Term-1 OR Intervention-Term-2 OR ...

OR Intervention-Term-n) AND

(biodiversity OR ((diversity OR richness OR abundance

OR density) AND (Outcome-Term-1 OR Outcome-

Term-2 OR ... OR Outcome-Term-n)))

While the search terms have been developed and will be applied in the English language only, non-English documents returned by these English search terms will be included in the systematic review. No time and document type restrictions will be applied.

\section{Grey literature}

We will cover a representative share of European grey literature by a complementary expert assessment. Selected experts from a broad range of European countries will synthesize personal expertise and grey literature for their specific country following a template to specify i.a. the role of multifunctionality in floodplain management and evidence for effects of multifunctional floodplain management approaches on biodiversity. Other ways of dealing with grey literature such as searches in Google Scholar and retrieving a limited number of hits (e.g. 50) as proposed by CEBC [36], seem to be less adequate for our purposes. These seemingly systematic procedures would produce a highly arbitrary selection, because (i) of the breadth of the topic (e.g. all floodplain management interventions, all taxa), (ii) the need for a simple search string, (iii) much relevant grey literature on the topic is written in non-English languages, (iv) much information was never adequately published, partly because commissioned studies were kept confidential or because they are part of larger and on-going floodplain management activities. The complementary expert assessment is almost completed at the time of compiling this protocol and will be published before the systematic review is written up. Consistency and differences of the findings of the two processes will be discussed in the discussion section of the systematic review.

\section{Literature provided directly by stakeholders}

Stakeholders were asked beforehand to provide literature. This literature was used to establish this systematic review protocol, but will also be considered for the definitive review. It will be reported, how many of the papers provided by the stakeholders overlap with those of the systematic search and how many of them were deemed suitable for assessment when applying the inclusion criteria.

\section{Comprehensiveness and effectiveness of the database search}

We tested the comprehensiveness of the search string in the following way: (i) we agreed on a short list of 6 expressions to be included regarding the population; (ii) we established extensive lists of 86 and 72 alternative terms for intervention and outcome, respectively; (iii) we evaluated the overall hits of the full query in the Scopus database; (iv) we evaluated the specific additional hits provided by each of the intervention-terms while keeping outcome constant; (v) we ranked the intervention terms according to their number of specific additional hits and assessed their cumulative hits by adding them one by one according to their relevance; and (vi) we repeated the last two steps for the outcome-terms while keeping the intervention-terms constant.

Consequently, we found that 37 of 86 terms for intervention (43\%) did not yield any specific additional hits, 
as was the case for 45 of 72 terms for outcome (62.5\%). Due to the long and flat plateaus of the saturation curves (Figure 1), we assume that our search string will adequately cover the relative literature. Thus, we will not search bibliographies of selected papers for potential additional literature except for identifiable review articles falling under the scope of this study, which will be searched for relevant primary studies. These primary studies detected in review articles will be treated in the same way as those identified directly by the search strings. The high proportion of alternative terms yielding zero or few additional hits might potentially be caused by having chosen the wrong terms, but this can be considered as highly improbable, because much literature was screened and many experts on the topic have been involved in the compilation of the lists.
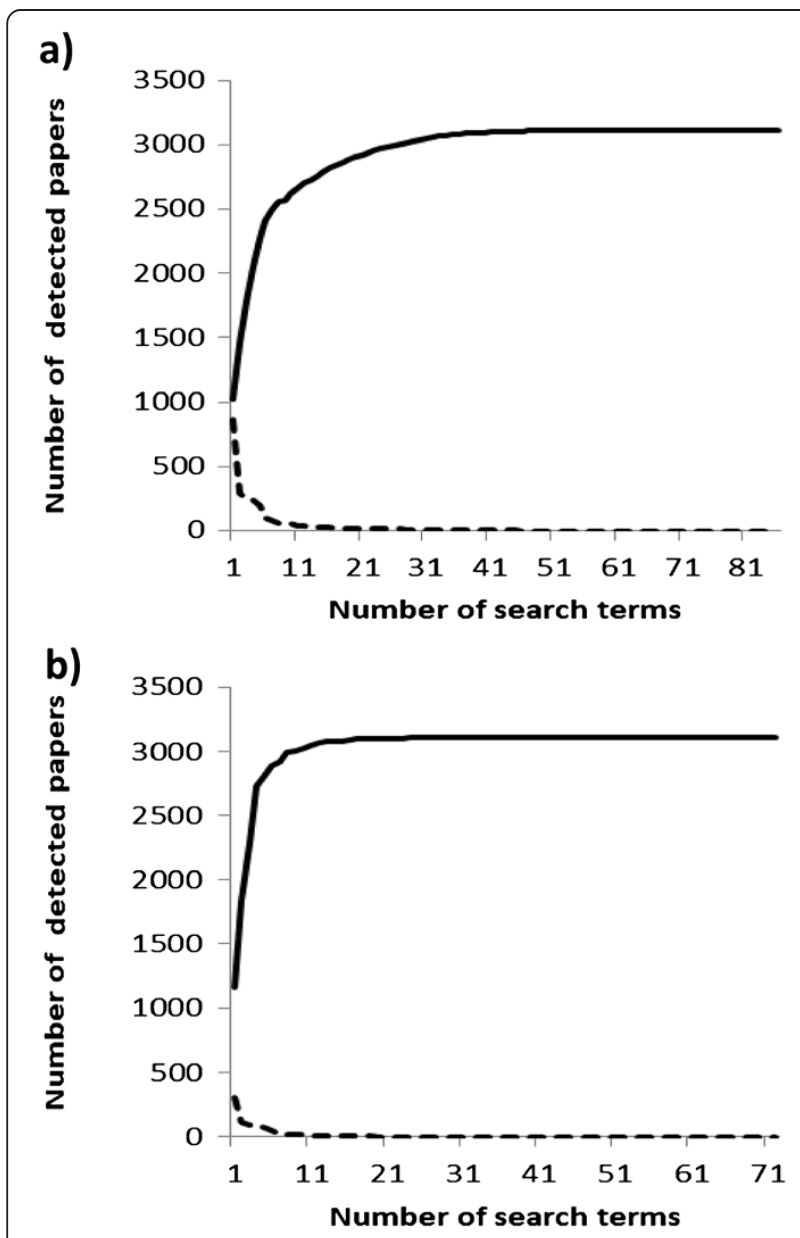

Figure 1 Saturation curves of the test searches for (a) intervention and (b) outcome. Full lines specify the cumulative hits when adding search terms one by one, dotted lines represent the specific additional hits for each alternative term. Terms were ranked according to their number of additional hits. These evaluations were performed with the Scopus database, keeping constant the search terms for the other aspect, respectively, and for "population".
To ensure the review is as comprehensive as possible we opted to keep the alternative terms that did not result in any additional hits in our search string, as keeping them will not require any further effort, but they might yield hits when using other combinations of terms, being translated to other languages, searching other databases or when searching in the future.

\section{Study inclusion criteria and study collection}

Articles identified by the search strategy will be filtered during a process consisting of three steps. First the inclusion criteria listed below will be applied to the titles of the studies. Titles often provide enough information (e.g. regarding the population or the geographical location) to clearly recognize incongruous articles which can subsequently be removed. The remaining articles will be filtered by viewing the abstract followed by the full text. Incongruity might occur and be detected in any of the three stages, because a study may obviously not match with the population (e.g. because it concerns a different kind of water body or does not match geographically or climatically), the intervention or the comparator (e.g. no intervention takes place or no comparator is used, while instead the study might describe the ecological status of a floodplain and recommend management measures), or will focus on different outcomes (e.g. geomorphology, water dynamics). If there is insufficient information to exclude a study, it will be kept in the database until the next stage.

To assess and limit the effects of between-reviewer differences in determining relevance, two reviewers will apply the inclusion criteria to a set of randomly chosen articles at the start of the abstract filtering stage. The kappa statistic [37] will be calculated, which measures the level of agreement between reviewers. If kappa is less than 0.6, the reviewers will discuss the discrepancies and clarify the interpretation of the inclusion criteria. This may entail a modification in the criteria specification. After this discussion, the reviewers will apply the inclusion criteria to the remaining articles. Studies reported in articles must achieve the following criteria to be included in the review and used for data extraction.

\section{Relevant population}

Floodplains including all ecosystems that are located in the morphological floodplain and linked to the hydrological regime of the river (e.g. rivers, oxbows, floodplain forests, flood-meadows, paddy fields) will be considered. Our focus is on large lowland floodplains and we excluded headwater streams (Strahler's river order $\leq 3$ ) and their floodplains for the purpose of this study. All other kinds of wetlands, such as lakes, estuaries, deltas and tidal flats, peatlands and fishponds [38] will not be considered.

We focus on environmental conditions that prevail in Europe, because this systematic review aims to support 
European decision-making. Evidence might come from other continents, but the environmental conditions should be similar to those in Europe. For this purpose, this systematic review will be limited geographically to the areas in both northern and southern hemispheres lying between the tropic and the polar circle, i.e. between $23^{\circ} 26^{\prime} 22^{\prime \prime}$ and $66^{\circ} 33^{\prime} 39^{\prime \prime}$, and climatically to the following Köppen-Geiger climate classes [39]: (i) "Dfc - Snow/fully humid/cool summer", (ii) "Dfb Snow/fully humid/warm summer", (iii) "Dfa - Snow/ fully humid/hot summer", (iv) "Cfb - warm temperate/ fully humid/warm summer", (v) "Cfa - warm temperate/ fully humid/hot summer", (vi) "Csb - warm temperate/ summer dry/warm summer", and (vii) "Csa - warm temperate/summer dry/hot summer".

\section{Types of intervention}

All types of intervention related to floodplain management will be considered. Such interventions are commonly related to production and transport, hydrological engineering and flood protection, conservation and restoration or recreation. Specific examples are for instance water extraction, navigational infrastructure, construction of dikes, construction of detention basins, removal of bank fixation, lowering of entrenchment depth, wood placement, installation of flow deflectors, elongation of river length, creating a new water course or multiple channels, extensification of land use and the reconnection of backwaters [26].

\section{Types of comparator}

We will only include studies that use comparators, and have identified the following three types when the outcome of interventions related to floodplain management is compared to (i) the previous state before the implementation of the intervention (e.g. [26]), (ii) the original natural state of the floodplain (mainly when assessing the performance of restoration measures, e.g. [40]) or (iii) to the state of a comparable floodplain after the implementation of another kind of intervention (e.g. [41]). Additional heterogeneity in the application of comparators in the primary studies will be caused by the different kinds of study designs (see section "Study quality assessment").

\section{Types of outcomes}

To be included, a study must assess the impact on biodiversity. As biodiversity (which implies the entire genetic, species and habitat diversity of an area) cannot be assessed directly, studies will use indicators of biodiversity. In this review, we will consider studies that assess impact on biodiversity expressed by indicators related to diversity or abundance of groups of organisms, such as species, other taxa (e.g. genus, families, subspecies), guilds (e.g. forest birds, rheophile fish), and functional or morphological groups (e.g. shredders, shrubs, macroinvertebrates) [27-30]. Studies that assess genetic and habitat diversity are also relevant, but will be excluded from the study and should be covered by future systematic reviews.

The indicators related to the diversity of groups of organisms include "diversity", which is commonly measured by diversity indices such as the Simpson or the Shannon Diversity Index, "richness", i.e. the number of species, "density", i.e. the number of species per spatial unit, and "evenness", i.e. evenness in number of individuals of each species in the area [42]. The indicators related to the abundance of groups of organisms include measures of abundance and density of specimens [43].

In the frame of this systematic review, we will evaluate for each relevant analyses encountered in a study (hereafter called "case"), whether the groups of organisms considered are specialists related to river dynamics and natural floodplain habitats and classify them accordingly during data extraction and for the synthesis.

\section{Types of studies}

We will include all kind of studies containing primary data about the impact of floodplain management on biodiversity (see also section "Study quality assessment").

\section{Potential effect modifiers and reasons for heterogeneity}

As we are tackling a broad topic, plenty of effect modifiers and reasons of heterogeneity are anticipated. We will extract several items of relevant information from the studies:

-) General study parameters: country, longitude, latitude, altitude, geographic zone, biogeographic realm, biome [44], Köppen-Geiger climate classes [40], investigated environment (artificial surfaces / agricultural areas / forests / wetlands, semiaquatic, mixed and others (including flooded meadows) / water), years of data collection, Strahler stream order, spatial extent of the study area, naturalness of the study area [45];

-) Methodological variables: the kind of intervention, time since implementation of the measure, study design (cf. Table 4), number of replicates of biodiversity plots per sampling site, sampling method, kingdom (animalia, plantae, fungi, protista, bacteria) and finer taxonomic categories (including functional groups), the size of the species pool (i.e. the number of potentially present species), outcome measure used (species richness, species diversity, etc.), statistical method applied.

\section{Study quality assessment}

Study quality assessment is required to add quality covariates to the analyses. Reviewers will assess the methodologies 
used in all articles accepted at full text. The quality assessment will be based on an evaluation of the following five criteria: (i) study design and repetitions, (ii) appropriateness of methods including statistics, and coverage in terms of spatial and temporal scale, (iii) intervention, intra-treatment variation, and confounding factors, (iv) baseline comparison, and (v) reliability of the study including presentation of consistency of methods and results, and missing values. Study quality will be scored following a hierarchy of evidence based on susceptibility to bias [46-48]. The particular system developed for the purpose of this review was adapted from the study quality assessment implemented by Stewart et al. [49]. Each criterion will be scored by the reviewer, and complemented by a short text specifying the reasons for the scoring. For example, a standardised study design like the BACI (Before/After/Control/Impact) type [50] would be of higher quality than a simpler design applying only spatial but not temporal control. The maximum overall score will equal 100 points (Table 4). The scoring might be different for each 'case' of analyses detected in a research paper, as it might be that sampling effort varies across considered taxa, or that primary analyses and results are presented incompletely for some cases. In the following, specifications of quality issues are presented for each of the five criteria:

(i.) Study design and repetitions are crucial aspects that determine the study results susceptibility to bias, robustness, explanatory power and generalizability [51]. Scoring will follow a scheme that considers study design expressed in temporal and spatial repetitions (Table 4).

(ii.) Appropriateness of methodology, and spatial and temporal coverage: appropriate sampling methods and statistical approaches are required to make best and unbiased use of information gathered. Validity and relevance of study results depends on the appropriateness of methods used and on the appropriate coverage in terms of the spatial and temporal scale of the study.

(iii.) Intervention, intra-treatment variation, and confounding factors: interventions might be badly specified or many different measures might be treated as 'interventions' and compared to control sites. Other confounding factors might lead to the conclusion that the study results might be prone to bias or error.

(iv.) Baseline comparison: in environmental sciences many studies might be confounded in terms of the baseline case selected, because the control sites are too different in regards their ecology or because they had been sampled at a large spatial or temporal distance or even with a different sampling protocol compared to the sampling units subject to interventions. (v.) Presentation of methods and results, reliability, and missing values: it is impossible to know the rigor that was implemented during all stages of a primary study. However, clarity and thoroughness of the presentation of methods and results might indicate overall scientific rigor and reduce the probability of wrong interpretations by the reviewer. Errors might occur during all stages of a study and confounding statements or very unreliable results in tables and figures that are not mentioned in the text or explained in the discussion, might indicate flaws in data processing or reasoning. Missing results for specific cases can lead to directional bias, for instance when only significant results are reported [52].

\section{Data extraction strategy}

Data will be extracted from each article and recorded in a spread sheet. One article can contain several cases of valid and relevant analyses and all of them will be extracted in different spread sheet rows. Data to be extracted will include the intervention and its level of multifunctionality, the outcomes, the methodology and other potentially confounding factors that have been identified as possible reasons for heterogeneity in the primary studies (see above Potential effect modifiers and reasons for heterogeneity).

A major issue in this systematic review is the assessment of whether and how the biodiversity impact of the interventions varies according to their level of multifunctionality. As the multifunctionality of the intervention is not directly obtainable from the primary literature, we will assess the level of multifunctionality for all important interventions based on their average effects on ESS provision. Each intervention might have either a positive, a negative or no influence on the provision of a specific ESS. The matrix concerning this matter will mainly be based on expert evaluations during workshops and teleconferences complemented by relevant information from literature sources. We will also consider ESS that might be related to 'secondary functions' or 'co-benefits' (sensu [53]). For the ESS classification, the "Mapping and Assessment of Ecosystem Services (MAES)"-scheme will be applied, which is based on the CICES classification [54] and has recently delivered its first applicable results [55]. We will consider 21 ESS and calculate for each intervention a multifunctionality index that equals the difference of the number of positively and negatively affected ESS divided by the overall numbers of considered ESS. This index will range between -1 (all ESS negatively affected) and +1 (all ESS positively affected) and interventions with positive values are supposed to increase the level of multifunctionality.

A further important issue is the extraction strategy related to the outcome, i.e. the biodiversity indicators, and 
we will evaluate for each case, whether the species of an assessed group of organisms are typical for and native to natural floodplain ecosystems.

Data extraction forms will be piloted on a purposive sample of the articles, to represent the range of articles available, and amended if necessary to improve repeatability and efficiency. For most study designs, we expect to extract $F, R, R^{2}$ values as well as p-values, sample sizes and degrees of freedom. Special care will be taken with regards potential publication bias that occurs when only significant results are presented in a paper that contains several kinds of analyses (e.g. related to subtaxa, subareas). Missing data for the most important issues (e.g. statistics, sample sizes, degrees of freedom) will be calculated or inferred where possible from the summary statistics presented: if not possible the authors will be contacted. Missing data regarding some of the covariates (altitude, years of data collection, Strahler stream order, etc.) will be researched, after being considered as relevant in the meeting of the stakeholder group.

\section{Data synthesis and presentation}

Initially a narrative synthesis of the data will be elaborated, and extracted cases will be grouped into hierarchical categories by intervention, also considering types of comparators, taxa, time since intervention and study quality. The exact categories will depend on the quality and type of data retrieved during the data extraction stage. One focus of the analyses will be on the evaluation of differences in effect size among established intervention types with apparent promise in a European context given their frequency of implementation and evidence from published accounts. The potential influence of the level of multifunctionality associated with different interventions will also be assessed. Additionally, we will test for the effects of the main covariates such as taxonomic kingdom, time since intervention, and habitat investigated. If extracted data are suitable for quantitative synthesis, we will aim to calculate effect sizes and carry out a meta-analysis [56,57]. Sensitivity analysis will be run to explore the effects of including studies with different designs and methodological quality. We will consider the different comparators in different analyses, as effect size has a totally different (even opposite) meaning when the effect of an intervention is compared to a previous unrestored situation or to the situation of a natural remnant. We will limit our analyses in the first instance to cases dealing with specialist floodplain species, and test later whether the same pattern can be detected for generalist species. Non-native species will be analysed separately, if the number of cases is high enough to enable a quantitative analyses.

If insufficient data are extracted, data are mainly of low methodological quality, or if the literature is too heterogeneous in regards to the interventions, we will limit our summary to a narrative synthesis and present the outcomes in tables and eventually systematic knowledge maps. Outcomes from addressing both the primary and secondary questions posed here will be discussed with selected stakeholder groups and implications for multifunctional floodplain management in Europe considered.

Table 4 Scoring sheet for study quality assessment

\begin{tabular}{|c|c|c|c|}
\hline Bias and generic data quality features & $\begin{array}{l}\text { Specific data quality } \\
\text { features }\end{array}$ & Quality element & $\begin{array}{l}\text { Quality } \\
\text { score }\end{array}$ \\
\hline \multirow[t]{12}{*}{ Selection and Performance bias: Study design } & Temporal repetition & Before-After (BA) Time Series (>1 replicates before and after) & 25 \\
\hline & & Interrupted BA Time series (>1 replicates before and after) & 20 \\
\hline & & BA comparison (1 Before, $>1$ After) & 15 \\
\hline & & BA comparison (>1 Before, 1 After) & 12 \\
\hline & & BA comparison (1 Before, 1 After) & 10 \\
\hline & & $\begin{array}{l}\text { Deficient BA comparison (e.g. Before-data from archives or not } \\
\text { from exactly the same sites) }\end{array}$ & 1 \\
\hline & & No BA comparison & 0 \\
\hline & Spatial repetition & Gradient of intervention intensity including "zero-control"-sites & 25 \\
\hline & & Site comparison (control/impact-Cl) & 15 \\
\hline & & Gradient of intervention intensity without "zero-control"-sites & 5 \\
\hline & & $\begin{array}{l}\text { Deficient } \mathrm{Cl} \text { comparison (e.g. Control-data from archives or not } \\
\text { from the same period) }\end{array}$ & 1 \\
\hline & & No Cl comparison & 0 \\
\hline Assessment bias: Measurement of outcome & $\begin{array}{l}\text { Replicates per treatment } \\
\text { (number of sites) }\end{array}$ & $\begin{array}{l}\text { Well replicated ( >4 replications) objective parameters measured in } \\
\text { several floodplain (sections) }\end{array}$ & 20 \\
\hline
\end{tabular}


Selection and Performance bias: Baseline comparison (heterogeneity between treatment and control arms with respect to defined confounding factors before treatment)
Sampling

Species composition

Habitat type

Other confounding environmental factors (floods, etc.)

Location

Selection and Performance bias: Intra treatment variation (heterogeneity within both treatment and control arms with respect to confounding factors)

\section{Intervention type}

Habitat type

Reliability of the presented evidence
Well replicated ( $>4$ replications) objective parameters measured in 12 a single floodplain (sections)

Replicated (1- 4 replications) objective parameters measured in 10 several floodplain (sections)

Replicated (1- 4 replications) objective parameters measured in 6 a single floodplain (section)

Unreplicated observations of objective parameters 2

Data gathered by expert opinion or questionnaire 0

Sampling method perfectly appropriate for purpose 2

Sampling method of restricted suitability 0

Large scale (large plots, long sampling sessions or large overall 2 extent) in relation to study aims and studies organisms

Intermediate scale in relation to study aims and studies organisms $\quad 1$

Small scale (small plots, short sampling sessions or small overall 0 extent) in relation to study aims and studies organisms

Treatment and control arms homogenous 2

Treatment and control arms not comparable with respect to 0 confounding factors OR insufficient information

Treatment and control arms homogenous 2

Treatment and control arms not comparable with respect to 0 confounding factors OR insufficient information

Treatment and control arms homogenous

Treatment and control arms not comparable with respect to confounding factors OR insufficient information

Treatment and control arms homogenous

Treatment and control arms not comparable with respect to confounding factors OR insufficient information

No heterogeneity within treatment and control arms

Replicates within treatment and control arms not comparable

No heterogeneity within treatment and control arms

Replicates within treatment and control arms not comparable

No heterogeneity within treatment and control arms

Replicates within treatment and control arms not comparable 0

Overall consistency and High

clarity of the paper Low 0

Statistical approaches Yes 2

appropriate

No

Clarity of the description High

of the method incl. statistical

models used

Low

Clarity of the presentation of High the results (incl. statistics)

Missing values for nonsignificant results causing publication bias

\section{0}

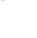

6

2

0

2

0

2

1

0

2

2

0

2

2

0


participating in the workshops. All authors read and approved the final manuscript.

\section{Acknowledgements}

We are grateful to Andrew Pullin and Barbara Livoreil for their support in systematic review methodologies, to Carsten Neßhöver, Marie Vandewalle, Estelle Balian, Isabel Sousa Pinto, Rita Araújo and Sonja Völler for discussions and advice related to the setting of the KNEU-demonstration cases, to Marco Fritz for providing insight and extra information on the topic, to Peter Søgaard Jørgensen and Alexandra Rogers for attending the first workshop, and to Katharina Zmelik for proof-reading. Two anonymous referees provided plenty of helpful comments on an earlier draft of the manuscript.

\section{Author details}

'Department of Conservation Biology, Vegetation \& Landscape Ecology, University of Vienna, Rennweg 14, Vienna 1030, Austria. ${ }^{2} \mathrm{CIBIO}$, Centro de Investigação em Biodiversidade e Recursos Genéticos, Universidade do Porto, Campus Agrário de Vairão, 4485-601 Vairão, Portugal. ${ }^{3}$ Essex Sustainability Institute, School of Biological Sciences, University of Essex, Colchester CO4 3SQ, UK. ${ }^{4}$ Department of Conservation Biology, UFZ Helmholtz Centre for Environmental Research, Permoserstr. 15, Leipzig 04318, Germany. ${ }^{5}$ Institute of Landscape Ecology, Slovak Academy of Sciences (ILE SAS), Štefánikova 3 , Bratislava 81499, Slovakia. ${ }^{6}$ United Nations University, Institute of Advanced Studies (UNU-IAS), Nishiku, Yokohama 220-8502, Japan. ${ }^{7}$ Dnipropetrovsk National University, prospekt Gagarina 72, 49010, Dnipropetrovsk DSP-10, Ukraine. ${ }^{8}$ Bundesamt für Naturschutz, Konstantinstraße 110, Bonn 53179, Germany. ${ }^{9}$ Ministry of Infrastructure and Environment, Rijkswaterstaat, Griffioenlaan 2, LA Utrecht 3526, the Netherlands. ${ }^{10}$ Environment Agency Austria (EAA), Spittelauer Lände 5, Vienna 1090, Austria. ${ }^{11}$ Research Institute for Nature and Forest (INBO), Kliniekstraat 25, Brussels 9500, Belgium. ${ }^{12}$ Ökológiai és Botanikai Intézet, Magyar Tudományos Akadémia, Ökológiai Kutatóközpont, Alkotmány u. 2-4., Budapest 2163, Hungary. ${ }^{13}$ Service conseil Zones alluviales, Rue des Pêcheurs 8A, Yverdon les Bains 1400, Switzerland. ${ }^{14}$ Fédération des Conservatoires d'espaces naturels, 6 rue Jeanne d'Arc, Orléans 45000, France. ${ }^{15}$ Karlsruhe Institute of Technology (KIT), Institute for Geography and Geoecology, Division WWF-Institute of Floodplain Ecology, Josefstrasse 1, Rastatt 76437, Germany. ${ }^{16}$ Department of Limnology of Shallow Lakes and Lowland Rivers, Leibniz Institute of Freshwater Ecology and Inland Fisheries, Müggelseedamm 301, Berlin 12587, Germany. ${ }^{17}$ Department of Landscape Ecology, Alterra, Wageningen UR, P.O. Box 47, Wageningen 6700 AA, The Netherlands. ${ }^{18}$ Institute for Environment and Human Security - United Nations University, Hermann-Ehlers-Str.10, Bonn 53113, Germany.

\section{Received: 13 August 2012 Accepted: 10 May 2013} Published: 23 May 2013

\section{References}

1. European Commission: Our life insurance, our natural capital: an EU biodiversity strategy to 2020. COM (2011) 244, Brussels; 2011.

2. Naumann S, McKenna D, Kaphengst T, Pieterse M, Rayment M: Design, implementation and cost elements of Green Infrastructure projects. Final report. Brussels: European Commission; 2011.

3. McDonald L, Allen W, Benedict M, O'Connor K: Green Infrastructure Plan Evaluation Frameworks. Journal of Conservation Planning 2005, 1:12-43.

4. European Commission: Green Infrastructure; 2010. http://ec.europa.eu/ environment/nature/info/pubs/docs/greeninfrastructure.pdf, last access: 2013 May 26.

5. European Commission: The Multifunctionality of Green Infrastructure. Brussels: Science for Environment Policy. In-depth Report; 2012.

6. European Commission: Green Infrastructure (GI) - Enhancing Europe's Natural Capital. COM (2013) 249, Brussels; 2013.

7. Costanza R, Folke C: Valuing Ecosystem Services with Efficiency, Fairness, and Sustainability as Goals. In Nature's Services: Societal Dependence on Natural Ecosystems. Edited by Daily GC. Washington DC: Island Press; 1997:49-70.

8. Naidoo R, Balmford A, Costanza R, Fisher B, Green RE, Lehner B, Malcolm TR, Ricketts TH: Global mapping of ecosystem services and conservation priorities. PNAS 2008, 105:9495-9500.

9. Isbell F, Calcagno V, Hector A, Connolly J, Harpole WS, Reich PB, SchererLorenzen M, Schmid B, Tilman D, van Ruijven J, Weigelt A, Wilsey BJ,
Zavaleta ES, Loreau M: High plant diversity is needed to maintain ecosystem services. Nature 2011, 477:199-203.

10. Maestre FT, Quero JL, Gotelli NJ, Escudero A, Ochoa V, Delgado-Baquerizo M, Garcia-Gomez M, Bowker MA, Soliveres S, Escolar C, Garcia-Palacios P, Berdugo M, Valencia E, Gozalo B, Gallardo A, Aguilera L, Arredondo T, Blones J, Boeken B, Bran D, Conceicao AA, Cabrera O, Chaieb M, Derak M, Eldridge DJ, Espinosa Cl, Florentino A, Gaitan J, Gatica MG, Ghiloufi W, GomezGonzalez S, et al: Plant species richness and ecosystem multifunctionality in global drylands. Science 2012, 335:214-218.

11. Naiman RJ, Décamps N, McClain ME: Riparia: Ecology, Conservation, and Management of Streamside Communities. New York: Elsevier; 2005.

12. Stanford JA, Lorang MS, Hauer FR: The shifting habitat mosaic of river ecosystems. In Proceedings of the International Association of Theoretical and Applied Limnology: 8-14 August 2004; Lahti, Finland. Stuttgart: Schweizerbart; 2005:123-137.

13. Tockner K, Lorang MS, Stanford JA: River flood plains are model ecosystems to test general hydrogeomorphic and ecological concepts. River Research and Applications 2010, 26:76-86.

14. Naiman RJ, Décamps H: The ecology of interfaces: riparian zones. Annu Rev Ecol Syst 1997, 28:621-658.

15. Ward JV, Tockner K, Schiemer F: Biodiversity of floodplains river ecosystems: ecotones and connectivity. Regulated Rivers: Research and Management 1999, 15:125-139.

16. Ward JV, Tockner K, Arscott DB, Claret C: Riverine landscape diversity. Freshw Biol 2002, 47:517-139.

17. Scholten M, Anlauf A, Büchele B, Faulhaber K, Henle K, Kofalk S, Leyer I, Meyerhoff J, Neuschulz F, Rast G, Scholz M: The Elbe River in Germany present state, conflicts, and perspectives of rehabilitation. Large Rivers 2005, 15:579-602.

18. Nilsson C, Jansson R: Floristic differences between riparian corridors of regulated and free-flowing rivers. Regulated rivers: Research and Management 1995, 11:55-66.

19. Poff NL, Allan JD, Bain MB, Karr JR, Prestegaard KL, Richter BD, Richter BD, Sparks R, Stromberg JC: The natural flow regime: a new paradigm for riverine conservation and restoration. BioScience 1997, 47:769-784.

20. Tockner K, Standford JA: Riverine flooplains: present state and future trends. Environ Conserv 2002, 29:308-330.

21. European Environment Agency (EEA): Assessing biodiversity in Europe - the 2010 report. Luxembourg: Office for Official Publications of the European Union; 2010.

22. Moss T, Monstadt J: Restoring Floodplains in Europe - Policy contexts and project Experiences. London: IWA Publishing; 2008.

23. Nijland $\mathrm{H}$, Menke U: Proceedings of the Conference Flood Risk Management and Multifunctional Land Use in River Catchments: Mainz, 17-19 October 2005. the Netherlands: Ministry of Transport, Public Works and Water Management; 2005.

24. Menke U, Nijland H: Flood risk management and river restoration; 2008 . http://www.ecrr.org/archive/conf08/pdf/proceed8.pdf, last access: 2013 May 26.

25. Bernhardt ES, Palmer MA, Allan JD, Alexander G, Barnas K, Brooks S, Carr J, Clayton S, Dahm C, Follstad-Shah J, Galat D, Gloss S, Goodwin P, Hart D, Hassett B, Jenkinson R, Katz S, Kondolf GM, Lake PS, Lave R, Meyer JL, O'Donnell TK, Pagano L, Powell B, Sudduth EB: Synthesizing U.S. River Restoration Efforts. Science 2005, 308:636-637.

26. Lorenz AW, Korte T, Sundermann A, Januschke K, Haase P: Macrophytes respond to reach-scale river restorations. J Appl Ecol 2012, 49:202-212.

27. Dziock F, Henle K, Foeckler F, Follner K, Scholz M: Biological indicator systems in floodplains - a review. Int Rev Hydrobiol 2006, 91:271-291.

28. Haase P, Hering D, Jähnig SC, Lorenz AW, Sundermann A: The impact of hydromorphological restoration on river ecological status: a comparison of fish, benthic invertebrates, and macrophytes. Hydrobiologia 2013, 704:475-488.

29. Paillex A, Dolédec S, Castella E, Mérigoux S, Aldridge DC: Functional diversity in a large river floodplain: anticipating the response of native and alien macroinvertebrates to the restoration of hydrological connectivity. J Appl Ecol 2013, 50:97-106.

30. Pander J, Geist J: Ecological indicators for stream restoration success. Ecol Indic 2013, 30:106-118.

31. Funk A, Reckendorfer W, Kucera-Hirzinger V, Raab R, Schiemer F: Aquatic diversity in a former floodplain: remediation in an urban context. Ecol Eng 2009, 35:1476-1484. 
32. Tszydel M, Grzybkowska M, Kruk A: Influence of dam removal on trichopteran assemblages in the lowland Drzewiczka River, Poland. Hydrobiologia 2009, 630:75-89.

33. Bernhardt ES, Sudduth EB, Palmer MA, Allan JD, Meyer JL, Alexander G, Follastad-Shah J, Hassett B, Jenkinson R, Lave R, Rumps J, Pagano L: Restoring rivers one reach at a time: results from a survey of US river restoration practitioners. Restor Ecol 2007, 15:482-493.

34. Miller SW, Budy P, Schmidt JC: Quantifying macroinvertebrate responses to in-stream habitat restoration: applications of meta-analysis to river restoration. Restor Ecol 2010, 18(1):8-19.

35. Kail J, Wolter C: Analysis and evaluation of largescale river restoration planning in Germany to better link river research and management. River Research and Applications 2011, 27:985-999.

36. Centre for Evidence-Based Conservation: Guidelines for Systematic Review in Environmental Management. Version 4.0. Environmental Evidence; 2010. www. environmentalevidence.org/Authors.htm, last access: 2013 May 26

37. Edwards AC, Creasey J, Skiba U, Peirson-Smith T, Cresser MS: Long-term rates of acidification of UK upland acidic soils. Soil Use and Management 1985, 1:61-65.

38. United Nations: Convention on Wetlands of International Importance especially as Waterfowl Habitat, Volume 14583. 1971st edition. Ramsar (Iran): UN Treaty; 1971. 2 February 1971.

39. Rubel F, Kottek M: Observed and projected climate shifts 1901-2100 depicted by world maps of the Köppen-Geiger climate classification. Meteorol Z 2010, 19:135-141.

40. Casanova SMC, Panarelli EA, Henry R: Rotifer abundance, biomass, and secondary production after the recovery of hydrologic connectivity between a river and two marginal lakes (Sao Paulo, Brazil). Limnologica 2009, 39:292-301.

41. Williams NM: Restoration of nontarget species: Bee communities and pollination function in riparian forests. Restor Ecol 2010, 19:450-459.

42. Magurran AE: Ecological Diversity and its Measurement. London: Chapman \& Hall; 1988

43. Feld CK, Martins Da Silva P, Sousa JP, de Bello F, Bugter R, Grandin U, Hering D, Lavorel S, Mountford O, Pardo I, Pärtel M, Römbke J, Jones KB SL, Harrison P: Indicators of biodiversity and ecosystem services: a synthesis across ecosystems and spatial scales. Oikos 2009, 118:1862-1871.

44. Olson DM, Dinerstein E, Wikramanayake ED, Burgess ND, Powell GVN, Underwood EC, D'Amico JA, Itoua I, Strand HE, Morrison JC, Loucks CJ, Allnutt TF, Ricketts TH, Kura Y, Lamoreux JF, Wettengel WW, Hedao P, Kassem KR: Terrestrial ecoregions of the world: a new map of life on earth. BioScience 2001, 51:933-938.

45. Machado A: An index of naturalness. J Nat Conserv 2004, 12(2):95-110.

46. Stevens A, Milne R: The effectiveness revolution and public health. In Progress in public health. Edited by Scally G. London: Royal Society of Medicine Press; 1997:197-225.

47. Pullin AS, Knight TM: Effectiveness in conservation practice: pointers from medicine and public health. Conserv Biol 2001, 15:50-54.

48. Rilov G, Mant R, Lyons D, Bulleri F, Benedetti-Cecchi L, Kotta J, Queirós AM, Chatzinikolaou E, Crowe T, Guy-Haim T: How strong is the effect of invasive ecosystem engineers on the distribution patterns of local species, the local and regional biodiversity and ecosystem functions? Environmental Evidence 2012, 1:10.

49. Stewart GB, Pullin AS, Coles CF: Effects of wind turbines on bird abundance. In Systematic Review No. 4. Birmingham: Collaboration for Environmental Evidence; 2005.

50. Smith EP: BACl design. In Encyclopedia of Environmetrics. Edited by El-Shaaraw AH, Piegorsch WW. Chichester: Wiley; 2002:141-148.

51. Henle K, Dziock F, Foeckler F, Follner K, Scholz M, Stab S, Hüsing V, Hettrich A, Rink M: Study design for assessing species environment relationships and developing indicator systems for ecological changes in floodplains - The approach of the RIVA project. Int Rev Hydrobiol 2006, 91:292-313.

52. Schafer JL: Analysis of incomplete multivariate data. Monographs on Statistics and applied Probability 72. Boca Raton USA: Chapman \& Hall; 1997.

53. Foster J, Lowe A, Winkelman S: The Value of Green Infrastructure for Urban Climate Adaptation. Washington DC: Center for Clean Air Policy; 2011.

54. Haines-Young R, Potschin M: Common International Classification of Ecosystem Services (CICES); 2011. http://unstats.un.org/unsd/envaccounting/ seeaLES/egm/Issue8a.pdf, last access: 2013 May 26.

55. Maes J, Teller A, Erhard M, Liquete C, Braat L, Berry P, Egoh B, Puydarrieux P, Fiorina C, Santos F, Paracchini ML, Keune H, Wittmer H, Hauck J, Fiala I
Verburg PH, Condé S, Schägner JP, San Miguel J, Estreguil C, Ostermann O, Barredo Jl, Pereira HM, Stott A, Laporte V, Meiner A, Olah B, Royo Gelabert E, Spyropoulou R, Petersen JE, et al: Mapping and Assessment of Ecosystems and their Services. An analytical framework for ecosystem assessments under action 5 of the EU biodiversity strategy to 2020. Luxembourg: Publications office of the European Union; 2013.

56. Borenstein M, Hedges LV, Higgins JPT, Rothstein HR: Introduction to MetaAnalysis. Chichester: John Wiley \& Sons Ltd; 2009.

57. Stewart G: Meta-analysis in applied ecology. Biology Letters 2010, 6:78-81.

doi:10.1186/2047-2382-2-10

Cite this article as: Schindler et al:: Floodplain management in temperate regions: is multifunctionality enhancing biodiversity? Environmental Evidence 2013 2:10

\section{Submit your next manuscript to BioMed Central and take full advantage of:}

- Convenient online submission

- Thorough peer review

- No space constraints or color figure charges

- Immediate publication on acceptance

- Inclusion in PubMed, CAS, Scopus and Google Scholar

- Research which is freely available for redistribution 